\title{
PENGGUNAAN BAHAN TUMPATAN DI RUMAH SAKIT GIGI DAN MULUT PSPDG FAKULTAS KEDOKTERAN UNSRAT PADA TAHUN 2014
}

\author{
${ }^{1}$ Dewi Y. Anang \\ ${ }^{2}$ Ni Wayan Mariati \\ ${ }^{2}$ Christy N. Mintjelungan
}

\author{
${ }^{1}$ Kandidat Skripsi Program Studi Pendidikan Dokter Gigi Fakultas Kedokteran \\ ${ }^{2}$ Program Studi Pendidikan Dokter Gigi Fakultas Kedokteran \\ Universitas Sam Ratulangi Manado \\ E-mail: dewianang.da@gmail.com
}

\begin{abstract}
Resin composite has been known since the sixtieth generation and generally it is known as the dentists' cosmetic restorative material. Amalgam is the oldest restorative material and it is famous due to its mechanical strength, endurance, and less expensive. Glass ionomer cement is an isochromatic tooth dentifrice; its main component is liquid consisted of water and polyacid, and a kind of fluoroaluminosilicate glass powder. This study aimed to obtain the profile of patients using dental restorative composite at the RSGM Manado in 2014. This was a descriptive retrospective study. There were 400 dental samples from the medical record categorized according to gender, age, kinds of treatment, and occupation. The results showed that dental treatment with filling was most frequent among females (65\%) compared to males (35\%). Most of the subjects (70\%) were 21-30 years old. Moreover, most of the subjects $(62.5 \%)$ used amalgam as the restorative material.
\end{abstract}

Keywords: restorative material, composite resin, amalgam, GIC

\begin{abstract}
Abstrak: Resin komposit ialah tumpatan pada generasi ke 60-an, dan secara umum dikenal sebagai bahan tumpatan kosmetik dentis. Amalgam merupakan bahan restorasi tertua dan cukup terkenal di masyarakat luas oleh karena kekuatan, daya tahan, dan harganya yang relatif murah. Glass Ionomer Cement ialah bahan tambal sewarna gigi yang komponen utamanya terdiri dari likuid yang merupakan gabungan air dengan polyacid (Asam poliakrilat, maleat, itakonat, tartarat) dan bubuk berupa fluoroaluminosilicate glass. Penelitian ini bertujuan untuk mengetahui gambaran pasien yang menggunakan tumpatan gigi di RSGM Unsrat pada tahun 2014. Jenis penelitian ini deskriptif retrospektif. Jumlah data penelitian yang didapat yaitu 400 sampel data dental dari rekam medik dan dikategorikan sesuai jenis kelamin, usia, jenis perawatan dan pekerjaan. Hasil penelitian menunjukkan perawatan dengan bahan tumpatan lebih sering dilakukan oleh pasien berjenis kelamin perempuan (65\%) dibandingkan laki-laki (35\%). Distribusi subyek terbanyak pada usia 21-30 tahun (70\%). Sebagian besar (62,5\%) menggunakan bahan tumpatan amalgam.
\end{abstract}

Kata kunci: tumpatan, resin komposit, amalgam, GIC

Ilmu bahan kedokteran gigi adalah ilmu yang mempelajari mengenai jenis bahan, komposisi, sifat-sifat, kegunaan serta cara penggunaannya. Bahan tumpatan berkembang di dunia kedokteran gigi, diantaranya tambalan resin komposit. Resin komposit 
merupakan bahan tambalan yang banyak digunakan di masyarakat, karena nilai estetiknya yang lebih bagus dibanding tambalan amalgam, sedangkan dari segi kekuatanya hampir sama dengan tambalan amalgam. Dengan meningkatnya kebutuhan estetik di bidang kedokteran gigi, dan pertimbangan mengenai sifat toksik merkuri saat tambalan amalgam distorsi membuat penggunaan restorasi resin komposit meningkat. ${ }^{1}$ Keberhasilan dalam suatu perawatan biasanya ditentukan oleh jenis bahan yang dipakai, oleh karena itu seorang dokter gigi dituntut harus mempunyai pengetahuan yang cukup tentang bahan-bahan kedokteran gigi yang digunakan

$\begin{array}{ccc}\text { Hasil Riset Kesehatan } & \text { Dasar } \\ \text { (RISKESDAS) pada tahun 2007, }\end{array}$ menunjukkan bahwa prevalensi penduduk yang memiliki masalah kesehatan gigi dan mulut terdapat pada kelompok usia muda yaitu memiliki karies sebesar 41,2\% dan melakukan perawatan sebesar $26,5 \%$, serta merupakan kelompok usia terbanyak yang menumpat gigi. Berdasarkan data hasil RISKESDAS, provinsi Sulawesi Utara merupakan salah satu dari 5 provinsi yang memiliki nilai tertinggi dalam masalah kesehatan gigi dan mulut yaitu $29,8 \%{ }^{2,3}$

Bahan tumpatan amalgam merupakan bahan restorasi tertua dan cukup terkenal dimasyarakat luas oleh karena kekuatan, daya tahan dan harganya yang relaif murah. Glass Ionomer Cement adalah bahan tambal sewarna gigi yang komponen utamanya yaitu likuid yang merupakan gabungan air dengan polyacid (asam poliakrilat, maleat, itakonat, tartarat) dan bubuk yang berupa fluoroaluminosilicate glass. ${ }^{4}$

Menurut survei awal di RSGM Manado, ditemukan banyaknya pemakaian jenis bahan tumpatan resin komposit, amalgam, dan GIC pada rekam medik. Hal ini yang menjadi alasan penulis untuk melakukan penelitian di RSGM tersebut.

\section{BAHAN DAN METODE PENELITIAN}

Penelitian ini merupakan penelitian deskriptif retrospektif yang dilaksanakan di
RSGM PSPDG FK Unsrat Manado. Populasi diambil dari rekam medik Departmen Konservasi Gigi di RSGM PSPDG FK Unsrat tahun 2014. Teknik pengambilan sampel yang digunakan yaitu total populasi.

\section{HASIL PENELITIAN}

Berdasarkan hasil penelitian ini yang menjadi sampel penelitian yaitu pasien yang melakukan tambalan gigi pada data rekam medik pasien tahun 2014 dengan total subjek penelitian 400 pasien.

Tabel 1 menunjukkan bahwa dari subjek penelitian 400 orang terdapat 260 orang (65\%) berjenis kelamin perempuan dan 140 orang (35\%) berjenis kelamin laki-laki.

Tabel 1. Distribusi subjek penelitian berdasarkan jenis kelamin

\begin{tabular}{ccc}
\hline Jenis kelamin & $\mathrm{n}$ & $\%$ \\
\hline Perempuan & 260 & 65 \\
Laki-laki & 140 & 35 \\
Total & 400 & 100 \\
\hline
\end{tabular}

Tabel 2 menampilkan distribusi subjek penelitian berdasarkan usia. Subyek terbanyak berusia 21-30 tahun mendapat 280 data sampel (70\%), sedangkan yang paling sedikit pada usia $\geq 60$ tahun dengan 8 data sampel (2\%).

Tabel 2. Distribusi subjek penelitian berdasarkan usia

\begin{tabular}{ccc}
\hline Usia (Tahun) & $\mathrm{N}$ & $\%$ \\
\hline$\leq 20$ & 45 & 11,25 \\
$21-30$ & 280 & 70 \\
$31-40$ & 42 & 10,5 \\
$41-50$ & 10 & 2,5 \\
$51-60$ & 15 & 3,75 \\
$\geq 60$ & 8 & 2 \\
Total & 400 & 100 \\
\hline
\end{tabular}

Tabel 3 menunjukan distribusi jenis bahan tumpatan. Jenis bahan tumpatan amalgam paling banyak digunakan di RSGM Manado pada tahun 2014 dengan total data sampel 250 (62,5\%.) Dibandingkan dengan bahan tumpatan 
resin komposit hanya mendapat 100 data sampel (25\%) sedangkan untuk GIC didapat 50 sampel (12,5\%).

Tabel 3. Distribusi subjek penelitian berdasarkan jenis bahan tumpatan

\begin{tabular}{ccc}
\hline Jenis Bahan Tumpatan & $\mathrm{N}$ & $\%$ \\
\hline Amalgam & 250 & 62,5 \\
Resin Komposit & 100 & 25 \\
Glass Ionomer Cement & 50 & 12,5 \\
Total & 400 & 100 \\
\hline
\end{tabular}

\section{BAHASAN}

Hasil bahasan tentang penggunaan bahan tumpatan pada tahun 2014 di RSGM Manado sebanyak 400 data sampel. Perawatan tambalan terutama terdapat pada jenis kelamin perempuan yaitu 260 data sampel, sedangkan pada jenis kelamin lakilaki sebanyak 140 data sampel. Hal ini membuktikan jenis kelamin perempuan sangat memperhatikan perawatan gigi khususnya penambalan serta sangat menjaga kesehatan gigi dan mulut. Di Instansi Kesehatan RSGM Manado paling banyak data sampel perempuan dibanding laki-laki.

Hasil penelitian yang sama juga dilaporkan oleh Soncini et al. di Inggris bahwa gigi yang sehat serta memiliki estetik yang baik merupakan hal yang sangat menunjang dalam penampilan kaum perempuan dan berpengaruh juga dalam meningkatkan rasa kepercayaan diri. ${ }^{5}$

Memiliki gigi yang rusak akibat karies, tentunya membuat perempuan merasa tidak nyaman akan kesehatan giginya dan rasa kepercayaan diri akan menurun. Apabila hal tersebut terjadi, pada perempuan akan langsung pergi ke dokter gigi untuk mendapatkan perawatan bagi gigi yang bermasalah. Jika dibandingkan dengan lakilaki yang cenderung tidak terlalu peduli terhadap penampilan maupun kesehatan gigi dan mulutnya. Sebagian besar laki-laki sudah merasa puas akan penampilan dan kondisi kesehatan gigi dan mulutnya. ${ }^{6}$

Hal ini sesuai dengan hasil survei yang dilakukan oleh American Dental Association (ADA) yang menyatakan bahwa kaum perempuan 89\% lebih rutin ke dokter gigi untuk merawat giginya dibandingkan laki-laki 75\%. Perempuan pada umumnya lebih rentan terhadap masalah kesehatan gigi karena adanya perubahan hormonal yang mereka alami.

Perubahan hormonal dapat memengaruhi aliran darah ke jaringan gingiva dan memengaruhi respon tubuh terhadap toksin yang dihasilkan oleh plak. Perubahan hormonal mengakibatkan perempuan menjadi lebih rentan terhadap penyakit jaringan periodontal (jaringan penyanggah gigi) dan karies gigi pada waktu tertentu dalam hidupnya. Salah satu fase dalam hidup seorang perempuan dimana terjadi perubahan hormonal yang dapat mengakibatkan dirinya menjadi lebih rentan terhadap masalah kesehatan gigi dalam hal ini karies gigi yaitu fase menopause. $^{8}$

Manifestasi oral akibat paska menopause meliputi penurunan saliva yang bisa menyebabkan proses karies meningkat. Menurunnya jumlah hormon estrogen yang terjadi pada masa menopause menyebabkan kaum perempuan memiliki resiko lebih tinggi untuk kehilangan densitas tulang. Kehilangan densitas tulang terutama pada rahang dapat mengakibatkan terjadinya gigi goyang. Resesi gingiva juga merupakan tanda kehilangan tulang pada rahang. Resesi gingiva dapat mengakibatkan lebih terbukanya permukaan gigi sehingga berpotensi terjadinya karies gigi. ${ }^{5,9}$

Distribusi subjek penelitian berdasarkan usia menunjukan persentase paling tinggi pada usia 21-30 tahun (70\%), sedangkan kelompok umur 51-60 tahun terdapat 15 data sampel (3,75\%). Hal ini membuktikan bahwa di usia muda lebih tinggi tingkat kesadaran untuk memelihara kesehatan gigi dan mulut bila dibandingkan dengan usia lanjut.

Hal ini sejalan dengan penelitian dari Chen et al. (2005) yang menyatakan bahwa semakin tinggi usia anak kesadaran semakin meningkat dan peluang untuk pergi ke dokter gigi dengan melakukan perawatan gigi khususnya untuk kasus karies dan melakukan penambalan sangat 
besar kesempatanya. Pada kelompok usia lansia kesehatan gigi dan estetiknya juga kurang diperhatikan. Kalaupun ada gigi mereka yang rusak, biasanya mereka lebih memilih untuk mencabut gigi mereka dan menggunakan gigi tiruan atau protesa. ${ }^{5,10}$

Distribusi subjek berdasarkan jenis bahan tumpatan menunjukan bahwa tumpatan amalgam yang paling sering dipakai dalam melakukan penambalan gigi, sedangkan bahan tumpatan resin komposit dan GIC yang paling sedikit pemakaiannya. Penulis berpendapat bahwa jenis bahan tumpatan amalgam banyak digunakan oleh karena jenis bahan ini memiliki harga yang relatif murah; selain itu tumpatan amalgam sifat mekanisme juga sangat kuat bila dibandingkan dengan tumpatan lainnya.

Menurut Shiny 2009 amalgam termasuk jenis bahan tambalan yang paling kuat dibandingkan bahan tambal Glass Ionomer Cement dan Resin Komposit dalam melawan tekanan kunyah, sehingga amalgam dapat bertahan dalam jangka waktu yang sangat lama di dalam rongga mulut. Secara estetik bahan tambalan amalgam kurang bagus, terutama untuk gigi depan, karena warnanya yang kontras dengan warna gigi, sehingga tidak dapat diindikasikan untuk gigi depan yang membutuh estetik. ${ }^{5}$

\section{SIMPULAN}

Pasien yang menggunakan bahan tumpatan amalgam sebesar 62,5\%, pengguna tumpatan resin komposit 25\%, dan GIC sebesar 12,5\%. Dengan hasil tersebut disimpulkan bahwa penggunaan bahan tumpatan amalgam lebih banyak disbanding bahan tumpatan resin komposit dan GIC.

\section{SARAN}

1. Disarankan untuk meningkatkan pelayanan terutama dalam hal penggunaan bahan tumpatan gigi.
2. Hasil penelitian ini diharapkan dapat menjadi informasi dan wawasan yang berguna bagi peneliti dan masyarakat dalam memilih bahan tumpatan yang sesuai dengan kebutuhan

\section{DAFTAR PUSTAKA}

1. Perben HB. Tambalan Amalgam Berbahaya Untuk Kesehatan. Jakarta: EGC, 2008; p. 1-69.

2. Soendoro T. Laporan Hasil Riset Kesehatan Dasar (RISKESDAS). Badan Penelitian dan Pengembangan Kesehatan Nasional 2007. Jakarta, 2008; p. 31-60

3. Zero D, Fontana $M$, Martinez E, Martinez A, Ando AA, Gonzalez C, Bayne S. The Biology, Prevention, Diagnosis and Treatment of Dental Caries. Scientific Advances in the United States. J Am Dent Assoc [ serial online] 2009 Sept [cited 2011 Nov 3]; Available from: URL: http://jada.ada.org/content/140/suppl_ 1/25S.abstract.

4. Irawan B. Material Restorasi Direk Kedokteran Gigi Saat Ini. J. Dentistry Indonesia. 2004;11(1):24-8.

5. B Mista Glass Ionomer Cement 2014 [cited 2015 July 20]; Available from: http://drgdewi09.blogspot.com/2010/ 12/gic-glass-ionomer-cement.htm.

6. Sumawinata N. Senarai Istilah Kedokteran Gigi. Jakarta: EGC, 2003; p. 69.

7. Darmanto Y. Mengapa bahan tambalan amalgam tidak dipergunakan lagi; 2008Des[2009Juni4];1(1):[1];URL http://mrdenstist.blogspot.com/2008/1 2denstist.

8. WA Dorland dictionnary (29th ed.). Jakarta, 2002; p. 273,321,1601.

9. Cohen S, Burns RC. Pathways of the pulp (9th ed.) St. Louis: Mosby, 2004; p. 21-3.

10.Lohbauer U, Miller FA, Petschelt A. Influence of surface roughness on mechanical strength of resin composite versus glass ceramic materials. J Dent Mater. 2008;24:3506. 